\title{
DELAYED LOSS OF THE ZONA PELLUCIDA FROM BLASTOCYSTS OF SUCKLING MICE
}

\author{
ANNE MaLAREN \\ A.R.C. Unit of Animal Genetics, \\ Institute of Animal Genetics, Edinburgh
}

(Received 16th February 1967)

\begin{abstract}
Summary. Mouse blastocysts retain the zona pellucida longer in lactating females when implantation is delayed than during normal pregnancy. For most of the period of delay, however, they are free of the zona, but do not induce Pontamine Blue reactivity in the uterus. The shed zonae often remain in the uterine lumen during the delay period without undergoing lysis.
\end{abstract}

When mice are ovariectomized in early pregnancy the blastocysts do not implant, and loss of the zona pellucida is delayed by about $12 \mathrm{hr}$ (Orsini \& McLaren, 1967). The time of loss of the zona thus depends, to some extent, on the uterine environment, as well as on the developmental stage of the blastocyst. The present experiment was designed to see whether a similar postponement of the loss of the zona occurs during physiological delayed implantation, i.e. in lactating mice. Dickson (1963) published photographs of zona-free blastocysts during lactational delay, but his data do not show at what stage the loss occurs.

Mice of the randomly bred $Q$ strain were used. Pregnant females were paired with males; those showing a vaginal plug within 2 days of the birth of the litter were assumed to have ovulated at 01.00 hours during the previous night. Some of the litters were killed on the morning that a plug was found. Females received $0.2 \mathrm{ml}$ of $0.5 \%$ Pontamine Sky Blue intravenously $15 \mathrm{~min}$ before autopsy to test for the presence of implantation sites. One or both uterine horns were flushed with phosphate-buffered saline, and the blastocysts examined at $100 \times$ magnification, measured and sometimes photographed. If there was any doubt as to whether the zona pellucida was present, the 'salt test' was applied, i.e. $\mathrm{NaCl}$ was sprinkled into the watch glass, increasing the tonicity so that the cellular portions of the blastocyst rapidly shrivelled, leaving the zona, if present, clearly visible.

The incidence of post-partum mating was low. In one series, only eleven out of twenty-six pregnant females placed with males of tested fertility showed postpartum plugs, while sixteen out of twenty control nulliparous females gave plugs during a 4-day period. 
A total of forty-three females with post-partum plugs was examined. On the 5 th day of pregnancy (Table 1), four out of nine non-lactating females showed Pontamine Blue areas, and most $(74 \%)$ of the blastocysts recovered were zonafree. None of the lactating females showed Pontamine Blue areas, and a significantly smaller proportion of their blastocysts $(44 \%)$ had lost the zona. By

\section{TABLE 1}

THE EFFEGT OF LAGTATION UPON THE LOSS OF THE ZONA PELLUGIDA AND THE APPEARANGE OF THE PONTAMINE BLUE REAGTION IN FEMALES MATED AT THE POST-PARTUM OESTRUS

\begin{tabular}{|c|c|c|c|c|}
\hline & \multicolumn{2}{|c|}{5 th day } & \multicolumn{2}{|c|}{6 th day } \\
\hline & Non-suckling & Suckling & Non-suckling & Suckling \\
\hline Time after ovulation & $\begin{array}{l}4 \text { days } 11 \mathrm{hr} \\
\text { to } 4 \text { days } 16 \mathrm{hr}\end{array}$ & $\begin{array}{l}4 \text { days } 12 \mathrm{hr} \\
\text { to } 4 \text { days } 17 \mathrm{hr}\end{array}$ & $\begin{array}{l}5 \text { days } 11 \mathrm{hr} \\
\text { to } 5 \text { days } 12 \mathrm{hr}\end{array}$ & $\begin{array}{l}5 \text { days } 10 \mathrm{hr} \\
\text { to } 5 \text { days } 12 \mathrm{hr}\end{array}$ \\
\hline Mean litter size & $10 \cdot 0$ & $9-8$ & $10 \cdot 7$ & $11 \cdot 6$ \\
\hline No. of females & 9 & 13 & 7 & 5 \\
\hline $\begin{array}{l}\text { No. containing Pontamine } \\
\text { Blue areas }\end{array}$ & 4 & 0 & 6 & 0 \\
\hline $\begin{array}{l}\text { Mean No. Pontamine Blue } \\
\text { areas where present }\end{array}$ & $12 \cdot 7$ & - & $12 \cdot 3$ & - \\
\hline $\begin{array}{l}\text { No. of females yielding } \\
\text { blastocysts }\end{array}$ & 9 & 13 & 2 & 5 \\
\hline $\begin{array}{l}\text { No. with half or more } \\
\text { blastocysts still in zona }\end{array}$ & 2 & 8 & 0 & 0 \\
\hline $\begin{array}{l}\text { No. of blastocysts } \\
\text { In zona } \\
\text { Zona-free }\end{array}$ & $\begin{array}{l}22 \\
62\end{array}$ & $\begin{array}{l}86 \\
67\end{array}$ & $\begin{array}{r}0 \\
12\end{array}$ & $\begin{array}{r}1 \\
47\end{array}$ \\
\hline
\end{tabular}

the 6th day of pregnancy (Table 1), however, all but one of the blastocysts even in lactating females were free of the zona, but implantation sites were still confined to those where the litters had been removed. By the 8th day of pregnancy (Table 2), implantation had still not begun except in those females

\section{EXPLANATION OF PLATE 1}

Fig. 1. Zona-free blastocyst, $150 \mu$ in length, flushed from the uterus of female 6 (Table 2), $7 \frac{1}{2}$ days after ovulation.

FIGs. 2 to $10.10 \mu$ TS of uteri, $7 \frac{1}{2}$ days after ovulation, fixed in formol saline and stained with haematoxylin and eosin. Figs. 7 to 9 are orientated with the mesometrial side of the uterus towards the top of the page, Fig. 10 with the mesometrial side to the right. The space in the lumen is a shrinkage artefact; before fixation, the walls of the lumen are pressed tightly together. Figs. 2 to 6,8 to $10, \times 440$; Fig. $7, \times 110$.

FIGs. 2 to 6 . Remains of shed zonae in the uteri of females 8 and 9 (Table 2).

FIG. 7. TS of left uterine horn of female 7 (Table 2). Blastocyst at antimesometrial end of uterine lumen, closely apposed to uterine epithelium.

Fig. 8. HP of Fig. 7.

FIG. 9. TS of blastocyst from left uterine horn of female 7 (Table 2), closely apposed to the side of the uterine lumen.

Fig. 10. TS of blastocyst at antimesometrial end of uterine lumen of female 9, passing through inner cell mass. 
PLATE 1
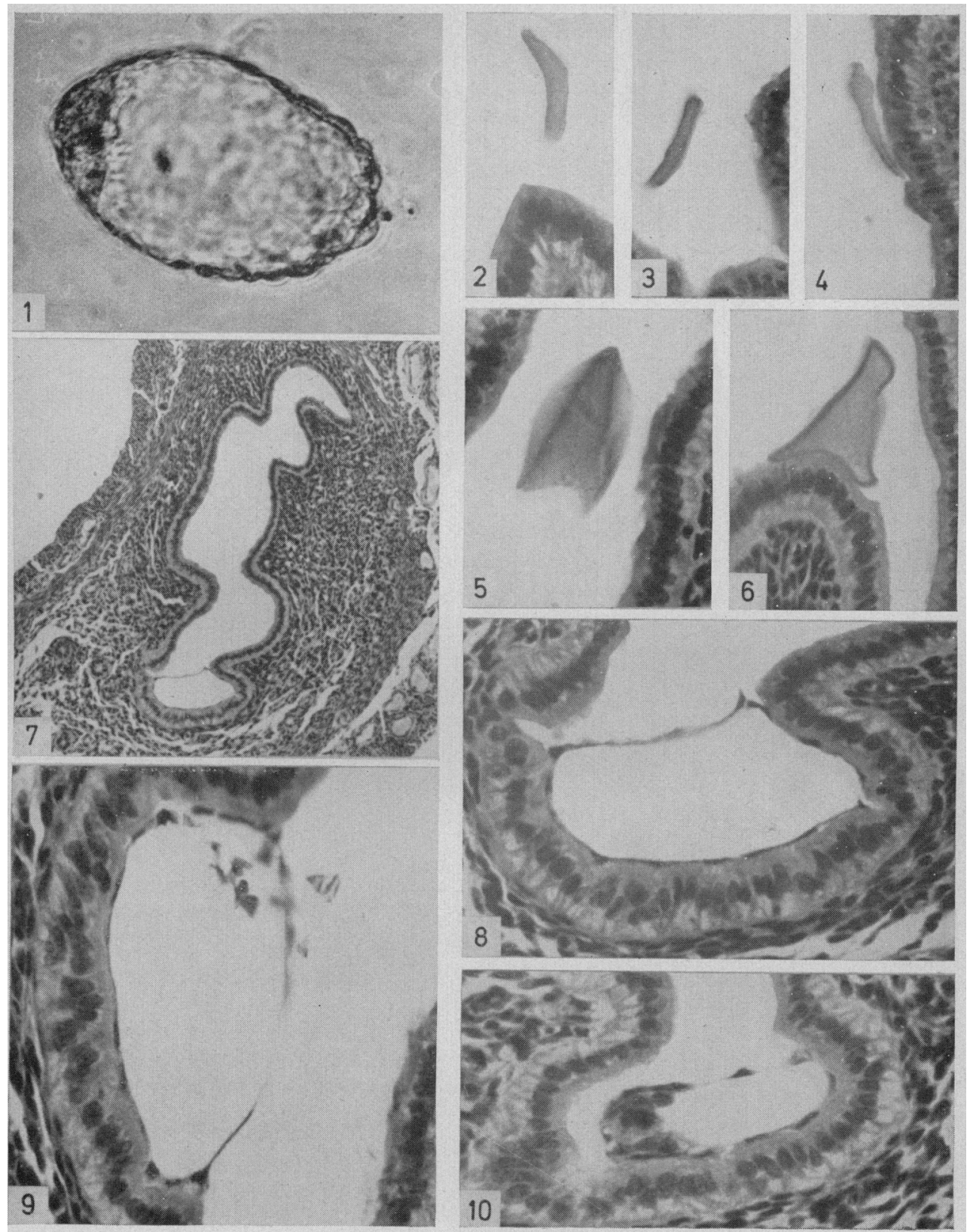

(Facing p. 160) 
where litter size was drastically reduced. In the others, blastocysts were zonafree, oval and 120 to $150 \mu$ in length (Pl. 1, Fig. 1).

One uterine horn from each of females 7, 8 and 9 in Table 2 was serially sectioned. Examination of these three horns revealed five, eight and seven blastocysts respectively. All were in close contact with the uterine epithelium (Pl. 1, Figs. 7 to 10) except where fixation shrinkage had torn the walls of the lumen apart. Most of the blastocysts were at the anti-mesometrial end of the lumen. No oedema or other local uterine reaction was observed (Finn \& McLaren, 1967). The uterine horns of females 8 and 9 also contained, respectively, five and seven structureless objects of uniform size which were interpreted as shed zonae (P1. 1, Figs. 2 to 6). This suggests that the failure of lysis of the zona pellucida which has been observed in mouse (Orsini \& McLaren, 1967)

TABLE 2

FEMALE MICE MATED AT THE POST-PARTUM OESTRUS, AND KILLED $7 \frac{1}{2}$ DAYS AFTER OVULATION

\begin{tabular}{|c|c|c|c|c|c|}
\hline \multirow{2}{*}{ Female } & \multicolumn{2}{|c|}{ No. of young } & \multirow{2}{*}{$\begin{array}{l}\text { Implant- } \\
\text { ation } \\
\text { sites }\end{array}$} & \multicolumn{2}{|c|}{ Blastocysts in one horn } \\
\hline & Born & Survived & & In zona & Zona-free \\
\hline $\begin{array}{l}1 \\
2 \\
3 \\
4 \\
5 \\
6 \\
7 \\
8 \\
9\end{array}$ & $\begin{array}{r}7 \\
11 \\
8 \\
10 \\
14 \\
12 \\
12 \\
15 \\
15\end{array}$ & $\begin{array}{r}0 \\
1 \\
4 \\
10 \\
11 \\
12 \\
12 \\
14 \\
14\end{array}$ & $\begin{array}{r}20 \\
15 \\
16 \\
0 \\
0 \\
0 \\
0 \\
0 \\
0\end{array}$ & $\begin{array}{l}- \\
- \\
\overline{-} \\
0 \\
0 \\
0 \\
\overline{0} \\
0\end{array}$ & $\begin{array}{l}- \\
- \\
\overline{4} \\
4 \\
5 \\
\overline{6} \\
3\end{array}$ \\
\hline
\end{tabular}

In females 1 and 2 , the swellings were at the stage of development expected on the 8th day of pregnancy, i.e. no delay had occurred; in female 3 , implantation had been delayed about 2 days. Only one uterine horn was flushed from each of females 4 to 9 ; the other was kept for histological examination.

and rat (Alloiteau \& Psychoyos, 1966) uteri in the absence of oestrogen stimulation, is also a feature of the lactational period.

Even in the control, non-lactating post-partum females (Table 1), the zona was retained longer than is usual in primiparous females (Orsini \& McLaren. 1967). In lactating females, as in ovariectomized females, it is retained longer still, until the second half of the 5th day on average. Nonetheless, for the greater part of the period of implantation delay, the blastocysts are without zonae and yet do not implant or stimulate Pontamine Blue reactivity in the uterus. In rats also, Psychoyos (1966) has concluded that implantation delay is not related to the persistence of the zona pellucida. The failure of the blastocyst to induce Pontamine Blue reactivity must be attributed to the hormonal state of the endometrium, rather than to any incompetence on the part of the blastocyst.

This investigation was supported in part by a grant from the Ford Foundation. 


\section{REFERENCES}

Alzoiteau, J. J. \& Psychoyos, A. (1966) Y a-t-il pour l'oeuf de ratte deux façons de perdre sa zone pellucide? C. r. hebd. Séanc. Acad. Sci., Paris, 262, 1561.

Dickson, A. D. (1963) Trophoblastic giant cell transformation of mouse blastocysts. J. Reprod. Fert. $6,465$.

Finn, C. A. \& McLaren, A. (1967) A study of the early stages of implantation in mice. F. Reprod. Fert. 13, 259.

Orsini, M. W. \& McLaren, A. (1967) Loss of the zona pellucida in mice, and the effect of tubal ligation and ovariectomy. F. Reprod. Fert. 13, 485.

Psychoyos, A. (1966) Influence of oestrogen on the loss of the zona pellucida in the rat. Nature, Lond. 211,864 . 